\title{
Honey mesquite influences on Chihuahuan desert vegetation
}

\author{
ALAN WARREN, JERRY HOLECHEK, AND MANUAL CARDENAS
}

\begin{abstract}
Authors are graduate research assistant and professor, Department of Animal and Range Sciences; and professor, Department of Exp. Statistics, New Mexico State University, Las Cruces, N.M 88003.
\end{abstract}

\begin{abstract}
Research has been lacking on the influence of honey mesquite (Prosupis glandulosa Torr.) on forage production in the Chihuahuan desert. In 1964 honey mesquite was controlled (65\% kill) with the herbicide, Monuron, on portions of the New Mexico State University College Ranch. Both herbicide treated and nontreated areas occur within the same pasture on similar soils and have similar grazing histories (continuous grazing, conservative stocking rate). This has resulted in areas with moderate and low levels of mesquite (16\% and $9 \%$ mesquite canopy cover, respectively). We evaluated relationships among forage standing crop, vegetation canopy cover, mesquite density, mesquite height, mesquite diameter, and mesquite volume on areas with low and moderate mesquite levels in fall 1992 and spring 1993. Regression analyses showed forage standing crop and canopy cover generally were not $(P>0.10)$ associated with mesquite height, mesquite diameter, canopy volume, and mesquite density on either low or moderate mesquite areas. Honey mesquite canopy cover on the non-treated area was nearly double that on the treated area. Data from long term permanent transects (1968-1992) showed no differences $(P>0.10)$ in total forage production between low and moderate mesquite areas in fall of 1992. On these transects mesquite increases in cover and density were over 3 times greater on the low compared to moderate mesquite areas in the 1982 to 1992 period. Our data indicate mesquite density and cover increase rapidly after herbicidal mesquite control even under conservative stocking. However at canopy cover levels below $17 \%$ honey mesquite appeared to have little effect on forage production. Potential maximum canopy cover of mesquite on these types of sites is about $37 \%$. Our data show that under proper stocking both mesquite and perennial forages grasses can increase concurrently on desert grassland ranges. We recognize that the outcome of our study may have been modified with higher mesquite densities, different soil characteristics or a lack of desirable understory species.
\end{abstract}

Key Words: rangelands, cattle, forage, brush management, range improvement

This paper was supported by the New Mexico Agr. Exp. Sta., Las Cruces, New Mexico and was part of project 1-5-27414.

Manuscript accepted 8 Apr. 1995.
Loss of forage from honey mesquite (Prosopis glandulosa Torr.) invasion of desert grasslands is an important concern of range managers. Problems with animal distribution and handling can also occur with increased mesquite density. Herbicidal control of mesquite has long been advocated as a quick means to increase forage production and improve range condition on arid rangelands in Texas, Arizona, and New Mexico (Norris et al. 1963, Valentine 1970, Abdulla 1980, McDaniel et al. 1982, Gibbens et al. 1992). Research has shown mesquite control can increase forage production for 5 to 10 years post treatment (Herbel et al. 1983, Gibbens et al. 1986). However studies on long term (10-30 years) effects of mesquite control on forage production are lacking.

The primary objective of our study was to evaluate the influence of honey mesquite density, height, diameter, canopy cover, and volume on forage standing crop and cover in the Chihuahuan desert of southcentral New Mexico. The areas selected for study had similar terrain, distance to water, soils, precipitation, and grazing history. Low honey mesquite (herbicidal control of mesquite in 1964) and moderate honey mesquite (no or limited mesquite control) areas were selected for study. Low and moderate honey mesquite areas are defined as having $9 \%$ and $16 \%$ canopy cover of honey mesquite, respectively. A secondary objective was to evaluate long term changes in forage standing crop and mesquite canopy cover on low and moderate mesquite areas using data collected in 1968, 1972, 1982, and 1992 from separate permanent transects.

\section{Study Area}

The study was conducted during fall 1992 (November) and spring 1993 (May) on the New Mexico State University College Ranch located $40 \mathrm{~km}$ north of Las Cruces, Doña Ana County, New Mexico. The College Ranch lies in the southern portion of the Jornada del Muerto Plain between the San Andres Mountains and the Rio Grande River. The elevation of the study area is $1,340 \mathrm{~m}$. Topography is generally level with all slopes less than $5 \%$. The area is arid, with no permanent water except for the river and stock watering points supplied by wells and temporary earthen tanks. Annual precipitation during the study period varied from 190 to $296 \mathrm{~mm}$, with a 30-year (1961 to 1990) average of $248 \mathrm{~mm}$ (Table 1). About half of the annual precipitation occurs 
Table 1. Average monthly precipitation (mm) on the New Mexico State University College Ranch study area.

\begin{tabular}{|c|c|c|c|c|c|c|c|c|c|c|c|c|c|}
\hline Month & 1982 & 1983 & 1984 & 1985 & 1986 & 1987 & 1988 & 1989 & 1990 & 1991 & 1992 & 1993 & $\begin{array}{c}\text { Long term } \\
\text { average } \\
1930-92\end{array}$ \\
\hline & & - . - . & - & - - & - & - & $-\mathrm{mm}$ & $\ldots$ & $\ldots$ & - . & $\cdots$ & - - - & $\cdots$ \\
\hline Feb & 7 & 13 & 0 & 6 & 10 & 11 & 32 & 15 & 10 & 13 & 4 & 12 & 9 \\
\hline Mar & 0 & 3 & 9 & 16 & 11 & 7 & 4 & 14 & 11 & 15 & 9 & 1 & 6 \\
\hline Apr & 0 & 20 & 0 & 10 & 2 & 3 & 11 & 0 & 13 & 0 & 29 & $\mathrm{~T}$ & 6 \\
\hline Jul & 21 & 16 & 25 & 45 & 58 & 32 & 70 & 49 & 75 & 74 & 13 & 11 & 41 \\
\hline Aug & 40 & 13 & 92 & 72 & 105 & 91 & 82 & 55 & 49 & 74 & 105 & - & 51 \\
\hline Sep & 67 & 51 & 9 & 63 & 37 & 7 & 23 & 14 & 56 & 53 & 6 & - & 36 \\
\hline Oct & 8 & 41 & 62 & 79 & 37 & 3 & 29 & 14 & 5 & 0 & 23 & - & 23 \\
\hline Nov & 15 & 27 & 26 & 3 & 72 & 8 & 1 & 2 & 19 & 22 & 14 & - & 12 \\
\hline Dec & 67 & 5 & 48 & 4 & 43 & 36 & 31 & 13 & 18 & 114 & 46 & - & 20 \\
\hline
\end{tabular}

$T=$ Trace amount.

between July and September with the highest precipitation in August. Wood (1969) described the climate of the area as semidesert with temperatures varying from $-23^{\circ}$ to $42^{\circ} \mathrm{C}$ and extreme daily fluctuations of $30^{\circ} \mathrm{C}$. June is the warmest month and January the coldest.

Soils of the College Ranch study area are mainly light loamy sandy loams underlain by calcium carbonate hardpan (caliche) at depths varying from a few centimeters to $1 \mathrm{~m}$ or more (Valentine 1970). They are classified as fine loamy, mixed, thermic, typic haplargids and are in the Simona-Cruces associations (SCS 1980). In areas where the ground cover is sparse, sandy dunes are formed around the invading mesquite plants (Wood 1969). Over most of the study area, the soil profile is relatively well preserved and stable.

Vegetation on the study area is characterized as Chihuahuan desert grassland, with shrubs scattered throughout the area. However, large portions have been invaded by honey mesquite (Prosopis glandulosa Torr.). Understory vegetation consists largely of black grama (Bouteloua eriopoda Torr.), mesa dropseed (Sparobolus flexuasus [Thurb.] Rybd.), and spike dropseed (S. contractus A. Hitch). Broom snakeweed (Gutierrezia sarothrae Greene) dominates a few small poor condition areas.

The College Ranch study pasture is classified as in good ecological condition (Tembo 1990), with the USDA Soil Conservation Service procedure developed by Dyksterhuis (1949). Remaining climax vegetation was approximately 65-70\% on the study pasture (Tembo 1990). On a long-term basis (the last 25 years), the study pasture has been stocked for an average utilization level of about $30 \%$ on the key forage species. During the 1986-1990 period the actual stocking range has averaged 48 ha per animal unit.

Several detailed vegetation inventories have been made on the study pasture since 1981 (McNeely 1983, Tembo 1990). Forage production and range condition scores increased between 1982 and 1990 . This change was attributed to both above average rainfall and conservative stocking.

Approximately $90 \%$ of the study pasture received herbicide treatment between 1957 and 1964 with either 2,4,5-T, Fenuron or Monuron (McNeely 1983, Tembo 1990). Percent actual kill of mesquite (tops and roots) ranged from 65 to $93 \%$. These treatments are discussed in detail by McNeely (1983) and Warren
(1993). In 1975 and again in 1985 the northern portion of the study pasture was aerially sprayed for mesquite but kills were less than 3\%. It is doubtful these treatments had any real effect on study pasture vegetation. The area selected for study with mesquite control had been treated with Monuron in 1964 . Between 65 and $85 \%$ of the mesquite was killed.

\section{Methods and Materials}

In August 1992 five transects $800 \mathrm{~m}$ in length and $200 \mathrm{~m}$ apart were systematically located along a ranch trail at the northern end of the study pasture in the area not treated for mesquite. Another 5 transects $800 \mathrm{~m}$ in length and $200 \mathrm{~m}$ apart were systematically located along the same ranch trail in the mesquite treated area in the southern portion of the pasture. The ranch trail used for transect location has been historically used to delineate chemical brush control treated and non-treated areas in the study pasture. All transects had a west to east orientation, and were similar in soils, topography, and distance from water $(1-2 \mathrm{~km})$.

During November 1992 and May 1993 transects were sampled at $50 \mathrm{~m}$ intervals for canopy cover of individual plant species by the "microline" technique (16 per transect) (Holechek and Stephenson 1983). A $1 \mathrm{~m}$ stick incremented in millimeters was used instead of an extended line. Every $100 \mathrm{~m}$ ( 8 per transect) a $0.5 \mathrm{~m}^{2}$ rectangular frame was clipped to determine standing crop $(\mathrm{kg} / \mathrm{ha}$ ) by species of palatable grasses and forbs (See studies by Rosiere et al. 1975, Hakkila et al. 1987). Green and yellow herbaceous material were separated from dead (gray) standing materials and placed in paper bags.

Each $0.5 \mathrm{~m}^{2}$ frame was used as the center point for a $10 \times 10 \mathrm{~m}$ quadrat. All mesquite plants within $100 \mathrm{~m}$ quadrats were measured for average canopy height, maximum canopy diameter, and minimum canopy diameter. These measurements were taken only in November 1992.

In 1967 permanent belt transects for comparison between mesquite treated and non-treated areas were established on the study pasture. These transects $(30.5 \mathrm{~m} \times 5 \mathrm{~cm})$ have been clipped annually in the fall for standing crop of black grama, threeawns, dropseeds, and annuals (grasses and forbs). 
Table 2. Significant $(P<0.10)$ Pearson correlation coefficients for plant standing crop $(\mathrm{kg} / \mathrm{ha})$ versus honey mesquite measurements on the College Ranch in southcentral New Mexico.

\begin{tabular}{|c|c|c|c|c|}
\hline $\begin{array}{l}\text { Plant } \\
\text { category }\end{array}$ & $\begin{array}{l}\text { Mesquite } \\
\text { measurement }\end{array}$ & $\begin{array}{l}\text { Level of } \\
\text { mesquite }\end{array}$ & Period & $\begin{array}{r}\text { Correlation } \\
\text { coefficient }\end{array}$ \\
\hline Black grama & Maximum diameter & Low & Fall 1992 & -0.309 \\
\hline Black grama & Volume & Moderate & Fall 1992 & 0.338 \\
\hline Black grama & Masimum diameter & Moderate & Spring 1993 & 0.287 \\
\hline Black grama & Minimum diameter & Moderate & Spring 1993 & 0.281 \\
\hline Mesa dropseed & \multicolumn{2}{|c|}{ No significant correlations } & \multicolumn{2}{|c|}{ - } \\
\hline Threeawn sp. & 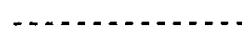 & . - - No significant correlations & $-\ldots$ & 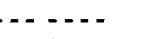 \\
\hline Total grasses & Volume & Moderate & Fall 1992 & 0.273 \\
\hline Non-poisonous forbs & Height & Low & Fall 1992 & 0.436 \\
\hline Non-poisonous forbs & Maximum diameter & Low & Fall 1992 & 0.270 \\
\hline Non-poisonous forbs & Height & Moderate & Spring 1993 & 0.287 \\
\hline Broom snakeweed & Height & Moderate & Spring 1993 & 0.289 \\
\hline Broom snakeweed & Maximum diameter & Moderate & Spring 1993 & -0.268 \\
\hline
\end{tabular}

Each year the belt transects were moved a minimum of $30 \mathrm{~cm}$ to avoid clipping the previous years sample. Mesquite density and cover were sampled in $30.5 \times 12 \mathrm{~m}$ belts on all permanent transects in 1982. The long term permanent transects were near our short tcrm fall 1992 and spring 1993 transects. Long term transect numbers on the mesquite treated and non-treated areas were 12 and 8 , respectively.

Unfortunately the permanent transect locations in the herbicide treated and non-treated areas were not presampled before the brush control treatment in 1964. However, empirical accounts by retired College Ranch personnel indicate range ecological condition was lower (higher mesquite cover) on treated than non-treated areas in the early 1960's before brush control. Selection of herbicide treatment areas was oriented toward lower forage producing areas. Due to a lack of records we cannot be completely sure that all the low mesquite area received herbicide treatment in 1964. However we are confident the high mesquite areas were untreated with herbicides.

A completely randomized design with repeated measures over time (seasons) was used to analyze all vegetation variables (SAS 1985). Pearson correlation coefficients were calculated for forage cover, forage standing crop, and mesquite measurements for both treatments and seasons. Honey mesquite volume was estimated using the technique of Ludwig et al. (1975).

Forage standing crop measurements for black grama, dropseeds, threeawns, and annual plants (forbs and grasses) from the long term permanent transects were statistically analyzed for differences $(P<0.10)$ using t-test with unequal variances.

\section{Results and Discussion}

Correlation coefficients for mesquite density, height, maximum diameter, minimum diameter, and volume with standing crop and canopy cover show mesquite had little influence on individual perennial grasses, total perennial grasses, non-poisonous forbs, broom snakeweed or other shrubs on either treated or non-treated areas (Tables 2 and 3). Black grama standing crop (fall 1992) in the non-treated area actually showed a weak positive $(P<0.10)$ correlation with mesquite volume, height, and diameter. Based on these data, it appears mesquite at the levels that occurred in our study has little influence on perennial grass production.

Total standing crop ( $\mathrm{kg} / \mathrm{ha}$ ) of grasses for the areas with moderate mesquite and low mesquite levels did not differ $(P>0.10)$ in either fall 1992 or spring 1993. Total grass standing crop means for data pooled across periods were 1,593 and $1,494 \mathrm{~kg} /$ ha for moderate and low mesquite levels, respectively. These forage estimates are substantially higher than those from other Chihuahuan desert studies (Paulsen and Ares 1962, Herbel et al. (1983). We explain our high forage levels by well above average growing season precipitation for the 1984-1992 period, above average winter rainfall in 1991 and 1992, favorable soils (sandy

Table 3. Significant $(P<0.10)$ Pearson correlation coefficients for plant canopy cover $(\%)$ versus honey mesquite measurements on the College Ranch in southcentral New Mexico.

\begin{tabular}{|c|c|c|c|c|}
\hline $\begin{array}{l}\text { Plant } \\
\text { category }\end{array}$ & $\begin{array}{l}\text { Mesquite } \\
\text { measurement }\end{array}$ & $\begin{array}{l}\text { Level of } \\
\text { mesquite }\end{array}$ & Period & $\begin{array}{l}\text { Correlation } \\
\text { coefficient }\end{array}$ \\
\hline Black grama & \multicolumn{4}{|c|}{ 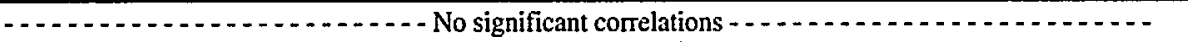 } \\
\hline Mesa dropseed & \multicolumn{4}{|c|}{ 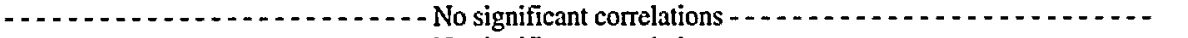 } \\
\hline Threeawn sp. & \multicolumn{4}{|c|}{ - } \\
\hline Total grasses & Height & Low & Spring 1993 & 0.339 \\
\hline Non-poisonous forbs & Height & Moderate & Spring 1993 & 0.276 \\
\hline Non-poisonous forbs & Maximum diameter & Moderate & Spring 1993 & 0.349 \\
\hline Non-poisonous forbs & Minimum diameter & Low & Spring 1993 & -0.308 \\
\hline Broom snakeweed & Height & Moderate & Spring 1993 & -0.288 \\
\hline Broom snakeweed & Maximum diameter & Moderate & Spring 1993 & -0.296 \\
\hline Other shrubs & Height & Moderate & Spring 1993 & -0.318 \\
\hline Other shrubs & Maximum diameter & Moderate & Spring 1993 & -0.314 \\
\hline
\end{tabular}


Table 4. Forage standing crop (kg/ha) means from low and moderate mesquite areas on the College Ranch in southcentral New Mexico.

\begin{tabular}{|c|c|c|c|c|c|c|c|c|c|}
\hline \multirow[b]{2}{*}{ Plant category } & \multicolumn{2}{|c|}{ Fall 1992} & \multicolumn{2}{|c|}{ Spring 1993} & \multirow{2}{*}{$\begin{array}{c}\begin{array}{c}\text { Fall } 92 \\
\text { Mean }\end{array} \\
\text {. }\end{array}$} & \multirow{2}{*}{$\begin{array}{l}\text { Spr. 93 } \\
\text { Mean }\end{array}$} & \multirow{2}{*}{$\begin{array}{l}\text { Low } \\
\text { Mean }\end{array}$} & \multirow{2}{*}{$\begin{array}{c}\text { Moderate } \\
\text { Mean }\end{array}$} & \multirow[b]{2}{*}{ Interaction } \\
\hline & Low & Moderate & Low & Moderate & & & & & \\
\hline & & & & & a) $\ldots$ & - ב & $\ldots$ & - . . . & \\
\hline Black grama & $19 \mathrm{~S}^{\mathrm{aa}}$ & $315^{\mathrm{aa}}$ & $728^{\mathrm{aa}}$ & $382^{\mathrm{aB}}$ & $256^{\mathrm{a}}$ & $555^{\mathrm{b}}$ & 463 & 348 & S, ST \\
\hline Threeawn sp. & $343^{\mathrm{aa}}$ & $529 \mathrm{ba}$ & $490^{\mathrm{ba}}$ & $223^{\mathrm{aB}}$ & 436 & 356 & 416 & 376 & ST \\
\hline Other grasses & $469^{a a}$ & $226^{\mathrm{aa}}$ & $17^{\mathrm{a} B}$ & $177^{\mathrm{aa}}$ & $347^{a}$ & $97^{\mathrm{b}}$ & 243 & 202 & S, ST \\
\hline Total grasses & 1490 & 1626 & 1697 & 1361 & 1558 & 1529 & 1593 & 1494 & NS \\
\hline Poisonous forbs & 23 & 11 & NP & NP & 17 & NP & NP & NP & NS \\
\hline Total standing crop & $1524^{a a}$ & $1983^{\text {ba }}$ & $1890^{\mathrm{ba}}$ & $1456^{a B}$ & 1753 & 1673 & 1707 & 1720 & ST \\
\hline
\end{tabular}

Different supercripts within rows and category reflect differences $(P<0.01)$ using LSD.

$\mathrm{ab}$ Rellect differences within season.

iB Reflect differences within treatment.

$S=$ indicates a season difterence.

$\mathrm{ST}=$ indicates a season by treatment interaction.

NS $=$ indicutes no significunt differences; $N E=$ not evaluated.

$\mathrm{NP}=$ no porsonous forbs were dipped in the spring so analysis was periomed only for Fall 1992.

Ioams with restrictive layer), and the conservative stocking rate (Holechek 1991). Also our sampling technique involved the inclusion of yellow with green material which undoubtedly caused our values to be high compared to other studies on the pasture evaluating only green material (Tembo 1990).

Black grama, mesa dropseed, threeawns, other grasses, nonpoisonous forbs, and poisonous forbs showed no real differences between moderate and low level mesquite areas in either standing crop or canopy cover although there were some treatment $\times$ period interactions (Tables 4 and 5).

Data from the long term transects were consistent with the short term transects in showing no differences $(P>0.10)$ between moderate and low mesquite areas in total perennial grasses or total standing crop in fall 1992 (Table 6). In 1968 and 1972 total perennial grass and total forage standing corp were higher on the moderate mesquite area. However forage standing crop on low and moderate mesquite areas converged in the period from 1972 to 1992. Possible explanations for the convergence include the beneficial effects of both past mesquite control and conservative stocking on the low mesquite area.

To further evaluate the influence of honey mesquite on vegetation changes on the study pasture we compared our 1992 mesquite density and canopy cover data with that collected on the same areas in 1982 by McNeely (1983). These data show mesquite densities and canopy cover increased more on low than on moderate mesquite areas (Table 7). These data and those from Table 6 show black grama, dropseeds, threeawns, total perennial grasses, and total forage standing crops all made major increases at the same time honey mesquite made a major increase. The increase in perennial grass standing crop was greatest on the low mesquite area which had the greatest increase in mesquite density and cover. These observations tend to further confirm that mesquite has small impact on forage production at cover levels below $17 \%$.

Many range researchers in the southwestern United States have considered mesquite invasion a major threat to livestock grazing

Table 5. Forage and shrub canopy cover (\%) means from low and moderate mesquite areas on the College Ranch in southcentral New Mexico.

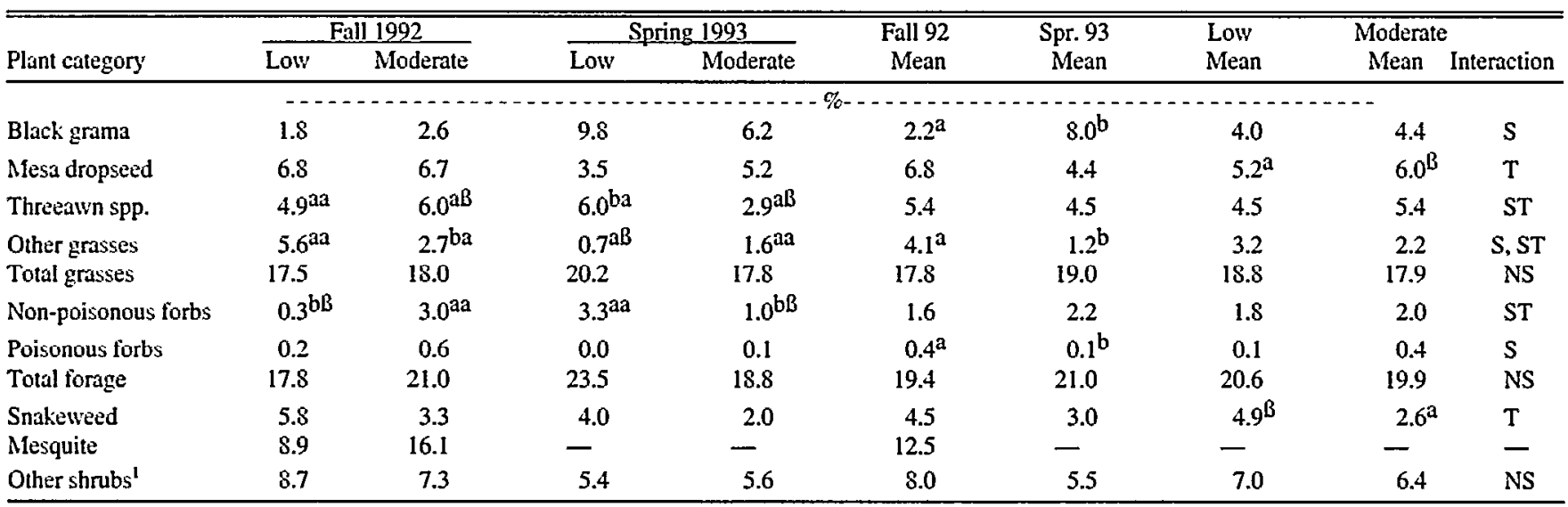

Different superscripts within rows and category reflect differences $(P<0.01)$ using LSD.

ab Reflect differences within season.

$a_{\text {Reflect difierences within treatment. }}$

$S=$ mulicates a season difference.

$S T=$ indicates a season by treatment interaction.

NS $=$ indicates no signilicant differences; $\mathrm{NE}=$ not evaluated.

=Fourving saltbush, Mormon tea, soaptree jucca, and pricklypear cactus. 
Table 6. Forage standing crop ( $\mathrm{kg} / \mathrm{ha}$ ) means for 1968,1972 , 1982, and 1992 from permanent transects in low and moderate mesquite areas on the College Ranch in southcentral New Mexico.

\begin{tabular}{lccc}
\hline \hline \multirow{3}{*}{ Plant category } & Year & $\begin{array}{c}\text { Low mesquite area } \\
\text { mean }\end{array}$ & $\begin{array}{c}\text { Moderate mesquite area } \\
\text { Black grama }\end{array}$ \\
\hline & 1968 & $(\mathrm{~kg} / \mathrm{ha})$ & $(\mathrm{kg} / \mathrm{ha})$ \\
& 1972 & 4.1 & 63.2 \\
& 1982 & 5.8 & 10.7 \\
Dropseed & 1992 & 0.1 & 49.3 \\
& 1968 & 19.7 & 71.7 \\
& 1972 & $21.0^{\mathrm{a}}$ & 103.3 \\
& 1982 & 43.1 & $94.1^{\mathrm{b}}$ \\
Threeawn & 1992 & 168.6 & 76.1 \\
& 1968 & 1.6 & 191.9 \\
& 1972 & 3.5 & 0.0 \\
Annuals & 1982 & 2.1 & 0.0 \\
& 1992 & 77.7 & 0.0 \\
& 1968 & $795.1^{\mathrm{a}}$ & 39.2 \\
& 1972 & 84.4 & $81.1^{\mathrm{b}}$ \\
& 1982 & 51.4 & 35.7 \\
Perennials & 1992 & 30.4 & 11.9 \\
& 1968 & $43.7^{\mathrm{a}}$ & 22.9 \\
& 1972 & $30.4^{\mathrm{a}}$ & $166.5^{\mathrm{b}}$ \\
& 1982 & 45.3 & $104.8^{\mathrm{b}}$ \\
Total forage & 1992 & 265.9 & 125.4 \\
& 1968 & $838.7^{\mathrm{a}}$ & 302.8 \\
& 1972 & 114.8 & $247.6^{\mathrm{b}}$ \\
& 1982 & 96.7 & 140.5 \\
& 1992 & 296.4 & 137.3 \\
& & 325.6 \\
\hline
\end{tabular}

${ }^{26}$ Superscripts within rows reflect differences $(P<0.01)$ using t-lest.

(Perennials $=$ blach grama + dropseed + threeawn).

(Total forage $=$ perenmals + annuals).

capacity (Glendening 1952, Buffington and Herbel 1965, Gibbens et al 1992). Our research is somewhat inconsistent with these observations. In order to properly interpret our results, a careful consideration of other studies examining the relationship between mesquite, forage production, drought, and grazing management is necessary. It is also important to consider site potential and degree of mesquite invasion.

Several researchers have questioned the potential of honey mesquite dominated ranges to improve without woody plant control (Glendening 1952, Paulsen 1953, Herbel et al 1983, Gibbens et al. 1986). Although research is limited, experimental evidence does indicate that grazing management and climatic trends may have more influence on the status of perennial grasses than increases in mesquite. It is important to recognize that woody plant (mesquite) increases may be at least partially due to their recovery from the intense drought in the 1950's (Betancourt et al. 1993). On Arizona desert range over a 28 year period (19411969), Smith and Schmutz (1975) found perennial grass basal cover nearly doubled on both grazed and protected sites on which mesquite crown cover more than tripled. The protected site had over twice the perennial grass basal cover of the grazed site in both 1941 and 1969.

In northcentral Texas, Scifres et al. (1974) examined the influence of honey mesquite control and grazing management on forage production. Eight years after spraying with 2,4,5-T moderately stocked, deferred-rotation grazed pastures had 4 times the mesquite canopy cover of heavily stocked continuously grazed pastures. However, perennial grass production across three sites was $47 \%$ higher under moderate, deferred rotation compared to heavy, continuous grazing $(1,413$ vs $959 \mathrm{~kg} / \mathrm{ha})$.
Table 7. Comparison of mesquite density and canopy cover data from 1982 (McNeely 1983) and 1992 data on low mesquite and moderate mesquite areas on the College Ranch in southcentral New Mexico.

\begin{tabular}{lccc}
\hline $\begin{array}{l}\text { Mesquite } \\
\text { level }\end{array}$ & Year & $\begin{array}{c}\text { Plants } \\
(\text { No./ha) }\end{array}$ & $\begin{array}{c}\text { Cover } \\
(\%)\end{array}$ \\
\hline Low & 1982 & 116 & 1.5 \\
Moderate & 1982 & 232 & 5.0 \\
Low & 1992 & 346 & 8.9 \\
Moderate & 1992 & 302 & 16.1 \\
\hline
\end{tabular}

On our study site, McNeely (1983) evaluated the influence of past (1959-1964) herbicidal control of honey mesquite on perennial grass cover and standing crop. In the period between 1968 and 1982, areas without mesquite control had a $20 \%$ increase in mesquite cover while areas with mesquite control (1958-1964) had no change. In this same period black grama, dropseed, and threeawn cover generally increased on non-treated areas but showed erratic responses on treated pastures.

Method of grazing had more influence than woody plant control on forage productivity in McNeely's (1983) study. Black grama, dropseeds, and threeawn all showed major increases in production between 1968 and 1982 on moderately stocked continuously grazed areas both with and without herbicide control. However, perennial grass production generally decreased on seasonally grazed areas. In 1982 forage production was highest (278 $\mathrm{kg} / \mathrm{ha}$ ) on continuously grazed areas without woody plant control. Herbicide treated areas had $262 \mathrm{~kg} / \mathrm{ha}$ on those continuously grazed and $170 \mathrm{~kg} / \mathrm{ha}$ on those scasonally grazed.

In recent years there has been a widely held view that grazing management alone has minimal potential to increase forage production on arid rangelands dominated by brush (Westoby et al. 1989, Laycock 1991). Although we acknowledge such situations, we believe they are more the exception than the rule. We support this conclusion with broad long-term studies from the Chihuahuan desert (McCormick and Galt 1993), and Salt desert (Yorks et al. 1992) as well the present study. These studies all show major increases in forage plants and improvement in range condition over 30-40 year periods if grazing intensities were moderate and precipitation was average or above average following drought.

Our study tends to provide support for the basic successional model of Clements (1916) and Dyksterhuis (1949) in which climate and grazing push the system either towards or away from climax. However, we do not reject that state-and transition model of Westoby et al. (1989). We believe if mesquite canopy cover levels were greater and if the seed source of perennial grasses was severely depleted meaningful range improvement would be unlikely.

Within the honey mesquite percent cover and density ranges we studied there appears to be no definite long-term relationship between mesquite and forage standing crop. Our results differ from a recent study on the adjacent Jornada Experimental Range that indicates mesquite dunelands, devoid of perennial forage, will develop over time on mesquite infested Chihuahuan desert grasslands unless herbicide treatment is applied at a 20-30 year interval (Gibbens et al. 1992). Prolonged drought conditions could reduce perennial forage and favor mesquite survival due to 
its deeper rooting. However, mesquite has some positive effects on forage plants. It provides grasses and forbs with enhanced soil nutrients (especially nitrogen because mesquite is a legume) and grazing protection (Wooten 1916, Buffington and Herbel 1965, Martin and Cable 1974).

The simultaneous increases of mesquite and perennial grasses in our study are consistent with long term studies by Potter and Krenetzky (1967), Smith and Schmutz (1975), and McNeely (1983). Mesquite canopy cover ranged from 0 to $37 \%$ on our sample plots. Scifres and Polk (1974) found it difficult to measure significant forage increase on mesquite control areas where mesquite canopy cover was less than 15-20\%. However, honey mesquite canopy cover above 15-20\% appears to negatively impact perennial forage cover based on studies from Texas (McDaniel et al. 1982) and Arizona (Glendening 1952). However this will very likely be site dependent.

\section{Experimental Limitations}

Differential grazing could occur in the study pasture due to location of roads and differences in primary preferred forages among season, or by weather patterns (wind direction) during various seasons. However, we do not believe it confounded our results. By choosing areas with both low and moderate mesquite levels for study we believe we removed concerns associated with differential grazing.

In both sampling seasons (fall 1992 and spring 1993) and during the previous 8 year period, precipitation was well above the long term average. Other studies show above average precipitation increases forage production more on areas with mesquite control compared to untreated areas while differences are minimized during drought (Dahl et al. 1977, Martin and Cable 1974). Average or below average precipitation could have changed our results.

\section{Management Implications}

Our study indicates that under proper stocking and above average annual precipitation both mesquite and perennial forage grasses can increase concurrently on desert grassland ranges. At some point, increases in mesquite may adversely affect perennial forage species.

Variable kill rates, retreatment costs, greater forage production variability between years, and limited duration of post treatment forage response can be drawbacks of brush control with herbicides. Mesquite control at the levels we studied in the Chihuahuan desert does not appear to cause enough increase in forage production to offset treatments costs and risk at current cattle prices (Holechek 1992, Holechek and Hess 1994). Presently it costs a minimum of about $\$ 25 /$ ha to control mesquite with herbicides. Available research indicates that forage production increases of about $135 \mathrm{~kg} / \mathrm{ha}$ are likely for the first 5 to 10 years after control on the best sites. However, benefits beyond this period are uncertain. Under the present cost/price structure this will increase returns by about $\$ 1.65 / \mathrm{ha}$. This means 15 years are needed just for a rancher to recover his investment with mesquite control under a best case scenario.

Stocking upland Chihuahuan desert ranges with residual peren- nial grasses to remove one third of current year annual growth on key forage species (black grama and mesa dropseed) appears to be a practical alternative to brush control, with a number of financial benefits discussed by Holechek (1992). Specific procedures and validation of procedures for conservative stocking of Chihuahuan desert ranges are provided by Holechek (1988) and Holechek and Pieper (1992). On soils (eg. coarse sands) with high cover of honey mesquite and lack residual perennial grasses grazing management alone will probably not give meaningful range recovery. In these situations woody plant reduction will probably be necessary for range improvement based on long term research (Herbel et al. 1972) and our empirical observations.

\section{Literature Cited}

Abdulla, S. H. 1980. Application of simulation techniques to evaluate grazing management policies in the semidesert grasslands of southem New Mexico. Ph.D. Diss., New Mexico State Univ., Las Cruces, N.M.

Betancourt, J. L., E. E. Pierson, K. A. Rylander, J. A. FairchildParks, and J. S. Dean. 1993. Influence of history and climate on New Mexico pinon-juniper woodlands. p. 42-63. In: Managing PinonJuniper Ecosystems for Sustainability and Social Needs. USDA Forest Serv. Gen. Tech. Rep. RM-236.

Buffington, L. C. and C. H. Herbel. 1965. Vegetational changes on a semidesert grassland from 1858 to 1963 . Ecol. Monog. 35:139-164.

Clements, F. E. 1916. Plant succession: an analysis of the development of vegetation. Carnegie Inst. Washington Pub. 242:1-512.

Dahl, B. E., R. E. Sosebee, J. P. Goen, and C. S. Brumley. 1977. Will mesquite control with $2,4,5-\mathrm{T}$ enhance grass production? J. Range Manage. 1:129-131.

Dyksterhuis, E. J. 1949. Condition and management of rangeland based on quantitative ecology. J. Range Manage. 2:104-115.

Gibbens, R. P., R. F. Beck, R. P. McNeely, and C. H. Herbel. 1992. Recent rates of mesquite establishment in the northern Chihuahuan desert. J. Range Manage. 45:585-588.

Gibbens, R. P., C. H. Herbel, H. L. Morton, W. C. Lindemann, J. A. Ryder-White, D. B. Richman, E. W. Huddleston, W. H. Conley, C. A. Davis, J. A. Reitzel, D. M. Anderson, and A. Guiao. 1986. Some impacts of 2,4,5-T on a mesquite duneland ecosystem in southern New Mexico: A synthesis. J. Range Manage. 39:320-326.

Glendening, G. E. 1952. Some quantitative data on the increase of mesquite and cactus on a desert grassland range in southern Arizona. Ecology 33:319-328.

Hakkila, M., J. L. Holechek, J. D. Wallace, D. M. Anderson, and M. Cardenas. 1987. Diet and forage intake of cattle on desert grassland range. J. Range Manage. 40:339-341.

Herbel, C. H., F. N. Ares, and R. A. Wright. 1972. Drought effects on a semi-arid desert grassland range. Ecology 5:1084-1093.

Herbel, C. H., W. L. Gould, W. F. Leifeste, and R. F. Gibbens. 1983. Herbicide treatment and vegetation response to treatment of mesquite in southern New Mexico. J. Range Manage. 36:149-151.

Holechek, J. L. 1988. An approach for setting the stocking rate. Rangelands 10:10-14.

Holechek, J. L. 1991. Chihuahuan desert rangeland, livestock grazing, and sustainability. Rangelands 13:115-120.

Holechek, J. L. 1992. Financial benefits of range management practices in the Chihuahuan desert. Rangelands 14:279-284.

Holechek, J. L. and K. Hess. 1994. Brush control considerations: a financial perspective. Rangelands 16:193-196.

Holechek, J. L. and R. D. Pieper. 1992. Estimation of stocking rate on New Mexico rangeland. J. Soil and Water Conserv. 47:116-119.

Holechek, J. L. and T. Stephenson. 1983. Comparison of big sagebrush in northcentral New Mexico under moderately grazing and grazing excluded conditions. J. Range Manage. 36:455-456.

Laycock, W. A. 1991. Stable states and thresholds of range conditions on North American rangelands. J. Range Manage. 44:427-433. 
Ludwig, J. A., J. F. Reynold, and P. D. Whitson, 1975. Size-biomass relationships of several Chihuahuan desert shrubs. Amer. Midl. Natur. 94:451-461.

Martin, S. C. and D. R. Cable. 1974. Managing semi-desert grassshrub ranges. USDA Forest Serv. Tech. Bull. No. 1480.

McCormick, J. C. and H. D. Galt. 1993. Forty years of vegetational trend in southwestem New Mexico. Abstract from Society of Range Management Meeting Feb. 1993. 46:47-48. Albuquerque, N.M.

McDaniel, K. C., J. H. Brock, and R. H. Haas. 1982. Changes in vegetation and grazing capacity following honey mesquite control. J. Range Manage. 35:551-557.

McNeely, R. P. 1983. Influence of mesquite on vegetational changes under two grazing strategies in southern New Mexico. M.S. Thesis, New Mexico State Univ., Las Cruces, NM.

Norris, J. J., K. A. Valentine, and J. B. Gerard. 1963. Mesquite control with Monuron, Fenuron, and Diuro. New Mexico State Agr. Exp. Sta. Bull. 484.

Paulsen, H. A., Jr. 1953. A comparison of surface soil properties under mesquite and perennial grass. Ecology 34:727-732.

Paulsen, H. A. and F. N. Ares. 1962. Grazing values and management of black grama and tobosa grasslands and associated shrub ranges of the Southwest. USDA Forest Serv. Tech. Bull. 1270.

Potter, L. D. and J. C. Krenetzky. 1967. Plant succession with release from grazing on New Mexico Rangelands. J. Range Manage. 20:145-151.

Rosiere, R. E., R. F. Beck, and J. D. Wallace. 1975. Cattle diet on semi-desert grassland: botanical composition. J. Range Manage. 28:94-96.

SAS. 1985. User's Guide. Statistics. Cary, N.C.
SCS. 1980. Soil survey of Dona Ana county, New Mexico. Soil Cons. Serv., USDA.

Scifres, C. J., M. M. Kothmann, and G. W. Mathis. 1974. Range site and grazing system influence regrowth after spraying honey mesquite. J. Range Manage. 27:97-100.

Scifres, C. J. and D. B. Polk. 1974. Vegetation response following spraying a light infestation of honey mesquite. J. Range Manage. 27:462-465.

Smith, D. A. and E. M. Schmutz. 1975. Vegetative changes on protected versus grazed desert grassland ranges in Arizona. J. Range Manage. $28: 453-458$.

Tembo, A. 1990. Influence of Watering Points and Range Condition on Vegetation of the Chihuahuan Desert. Ph.D. Diss., New Mexico State Univ., Las Cruces, N.M.

Valentine, K. A. 1970. Influence of grazing intensity on improvement of deteriorated black grama range. New Mexico State Univ. Agr. Exp. Sta. Bull. 553.

Warren, A. 1993. Long term mesquite control influences on Chihuahuan desert vegetation. M.S. Thesis, New Mexico State Univ., Las Cruces, N.M.

Westoby, M., B. Walker, and I. Noy-Meir. 1989. Opportunistic management for rangelands not at equilibrium. J. Range Managc.42:266-274.

Wood, J. E. 1969. Rodent populations and their impact on desert rangelands. New Mexico State Univ. Agr. Exp. Sta. Bull. 555.

Wooton, E. O. 1916. Carrying capacity of grazing ranges in southern Arizona. USDA Bull. 367.

Yorks, T. P., N. B. West, and K. M. Capels. 1992. Vegetation differences in desert shrublands of western Utah's Pine Valley between 1933 and 1989. J. Range Manage. 45:569-578. 